\title{
空圧ステージを駆動する空気圧シリンダの圧力応答を考慮した制御系の適用
}

\author{
石井 浩貴 ${ }^{* 1}$, 涌井 伸二*2
}

\section{Application of control system considering pressure response of air cylinder for pneumatic stage}

\author{
Hiroki ISHII $^{* 1}$ and Shinji WAKUI ${ }^{* 2}$ \\ ${ }^{{ }^{* 1}}$ Graduate School of Engineering, Tokyo University of Agriculture and Technology \\ 2-24-16 Naka-cho, Koganei-shi, Tokyo 184-8588, Japan \\ ${ }^{* 2}$ Institute of Engineering, Tokyo University of Agriculture and Technology \\ 2-24-16 Naka-cho, Koganei-shi, Tokyo 184-8588, Japan
}

Received: 22 August 2018; Revised: 25 December 2018; Accepted: 10 May 2019

\begin{abstract}
In the pneumatic stage, the differential pressure is the driving force. For this reason, it is indispensable for fast positioning to change the pressure in the chamber instantaneously. The piston in the air cylinder moves when the stage is driven. As a result, the volume of the chamber increases or decreases during positioning. Therefore, the pressure in the chamber changes not only by the opening and closing operations of the left and right servo valves but also by the increase and decrease of the chamber volume. Here, in order to drive the stage under high-speed, the chamber volume must be rapidly changed. At this time, the influence of the pressure change due to the chamber volume cannot be ignored and the differential pressure becomes small. This hinders realization of fast positioning. Therefore, the pressure response is improved so that the pressure change due to the servo valves is more dominant than that due to the chamber volume. In this paper, we propose opening operation of the exhaust side valve. It was demonstrated that symmetrization of left and right pressure responses using the proposed method enables fast positioning. Furthermore, it was confirmed that similar effects can be obtained in the control system in combination with pressure feedback.
\end{abstract}

Keywords : Positioning, Pneumatic equipment, Motion control, Pressure control, PDD $^{2}$ compensator

\section{1. 緒言}

空気圧シリンダは圧縮空気を動力源とするアクチュエータであり，価格の低廉さ，取り扱いの容易さ，清潔 さ, そして安全さのために各種産業現場で利用されている（京和泉他，2004）（Kawashima et al., 2010).さらに, 発熱や磁気漏洩が無く, 今後は電子ビーム露光装置内の位置決めステージとしての応用が期待されている. そ のため, 位置決め手法の研究が多岐にわたって行われている．高速位置決めについてはステージジャークフィ ードバック (Stage jerk feedback: 以下, SJFB と略記)（Wali and Wakui, 2013), 圧力フィードバック (Pressure feedback: 以下, PresFB と略記)（涌井, 多田, 2008）などが, 高精度位置決めについてはモデル追従制御（Ito et al., 2016)，流量外乱オブザーバ（柳川，涌井，2010）などが挙げられる.

一方で，同シリンダの駆動力は，バルブの開閉動作に伴う空気の給排気によりシリンダ内のチャンバ間に生 じる圧力差である，そのため，高速な位置決めには十分な圧力差を瞬時に発生する圧力応答が望まれる，よっ て, 空気供給側のチャンバ内圧の素早い上昇, 排気側のチャンバ内圧の素早い低下が要求される.つまり, 左 右の圧力変化は対称性を持つ.しかし, 空気の圧縮性により実際の圧力応答と所望のそれは乘離する. 文献（宮 田，花房，1990）では，シリンダ内のピストンの運動に伴って給気側の圧力が十分に上昇せず，排気側の圧力 がむしろ上昇する現象が報告されている，同文献では，速度フィードフォワード補償により，圧力目標值に対

\footnotetext{
No.18-00335 [DOI:10.1299/transjsme.18-00335], J-STAGE Advance Publication date : 20 May, 2019

*1 学生員, 東京農工大学大学院工学府（干184-8588 東京都小金井市中町 2-24-16）

*2 正員, 東京農工大学大学院工学研究院

E-mail of corresponding author: s186185r@st.go.tuat.ac.jp
} 
する実測の圧力の追従性の改善が確認され，排気側で適切に圧力が低下するようになった．しかし，位置決め 時の両チャンバの圧力変化の対称化という点では不十分である. また, 文献（宮田他，1990）ではピストン位 置の差異, 寸なわちチャンバ体積の差異に起因した圧力応答のばらつきが報告されている. 同文献では, チャ ンバ体積を電気的に増加させる作用を持つ圧力微分フィードバック（白石他，2007）を用いた可変ゲイン PD (proportional + derivative) 圧力制御系をインナループとして有する二重フィードバック構造の位置制御系が提案 され，その有効性が示されている．同圧力制御系では，ピストン位置と対応した可変ゲインにより左右のバル ブ開度を操作する. これにより, 左右のチャンバ内の圧力応答が対称化され, 応答が改善されている. しかし, 圧力応答の改善は, 圧力変動の補償に根ざしており, 制御構成が複雑になる. また, サーボバルブの非線形性 を補償する流量フィードバック（加藤他，2009）では，チャンバ体積の減少に起因する圧力応答を整形できな い.

そこで，文献（宮田，花房，1990）（宮田他，1990）で示された空気圧駆動を本質的に圧力制御系とみなす設 計思想を踏襲しつつ，圧力応答を簡単に対称化する制御系を検討する．本論文では，バルブ開度の非対称化を 行う. 具体的には, 左右のバルブ操作量に任意のゲインを乗算することでバルブ開度を操作し，圧力応答を改 善できることを実験的に検証する．まず 2 章では, 実駼構成と位置決めについて述心゙, 位置決め実験結果より 圧力応答の改善が必要であることを示す. 次に 3 章では提案手法の原理・現象を確認し, 有効性を検証する. さらに，4章で PresFB との併用時の効果について確認する. 最後に 5 章で結論を述べる.

\section{2. 空圧ステージの実験構成と位置決め}

\section{$2 \cdot 1$ 実験環境}

図 1 に空圧ステージを示寸. 同ステージは転がり軸受で案内され, 一直線に駆動される. ここでは, 同ステ ージを 1 次遅れの空圧系と 2 次遅れの機械系の直列接続としてモデル化する. 図 2 に同ステージを含む実験構 成を示す．エアコンプレッサで生成される圧縮空気はレギュレータで減圧かつ平滑化された後，サーボバルブ

(LINATOR, EWS 3/4）に供給される. 同バルブは左右に一つずつ設置されており, 受圧面積 $198 \mathrm{~mm}^{2}$, ストロ ーク $300 \mathrm{~mm}$ の空気圧シリンダ（Airpel, M16D300.0S）のチャンバに流入・流出する空気の流量を別個に制御す る. その結果, 位置決め指令に応じてチャンバ間に圧力差を生じ, 高圧力側から低圧力側へステージが駆動さ れる．なお，バルブから空気圧シリンダまでの配管長は左右ともに $3.3 \mathrm{~m}$ ，内径 $5 \mathrm{~mm}$ である．ステージ位置は 差動変圧器（Linear variable differential transformer：以下, LVDT と略記）（SHINKO ELECTRIC, LT2-120R）で検 出される. 取得した位置信号はDSP に入力され, 次節で後述する制御則に基づいたバルブ操作量が決定される. また，ステージに対して左側のチャンバ内圧を圧力センサ（Setra, Model 204）で，チャンバに流入する空気の流 量を流量計（COSMO INSTRUMENTS, DF-240BA）で測定し，DSP で記録する.

\section{$2 \cdot 2$ 制御構成}

図 3 に空圧ステージの制御構成を，図中で用いた記号を表 1 に示寸. 配管，サーボバルブ，シリンダで構成 される空圧系は積分特性を有する. そのため, 位置補償器としては PID 補償器の 1 階微分に相当する $\mathrm{PDD}^{2}$ 補償

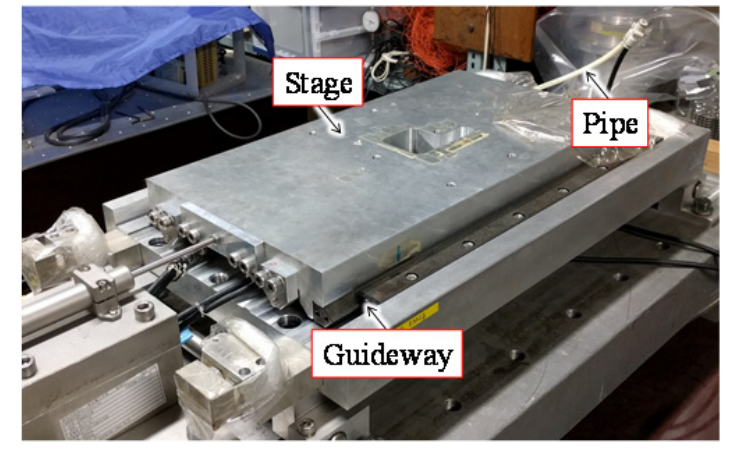

Fig.1 Photograph of pneumatic stage.

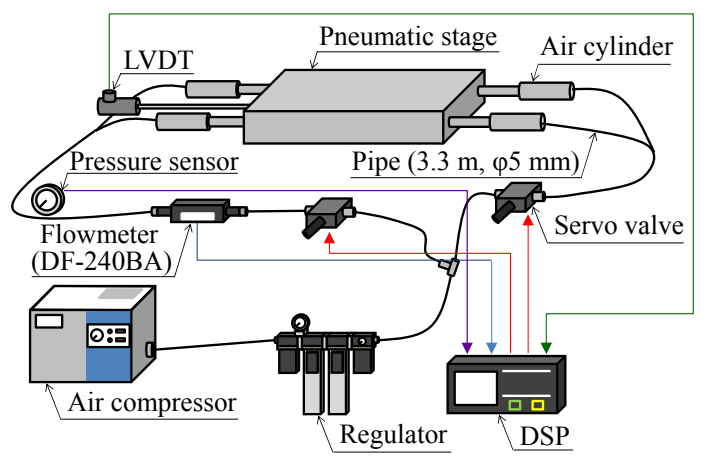

Fig. 2 Schematic diagram of experimental setup. 


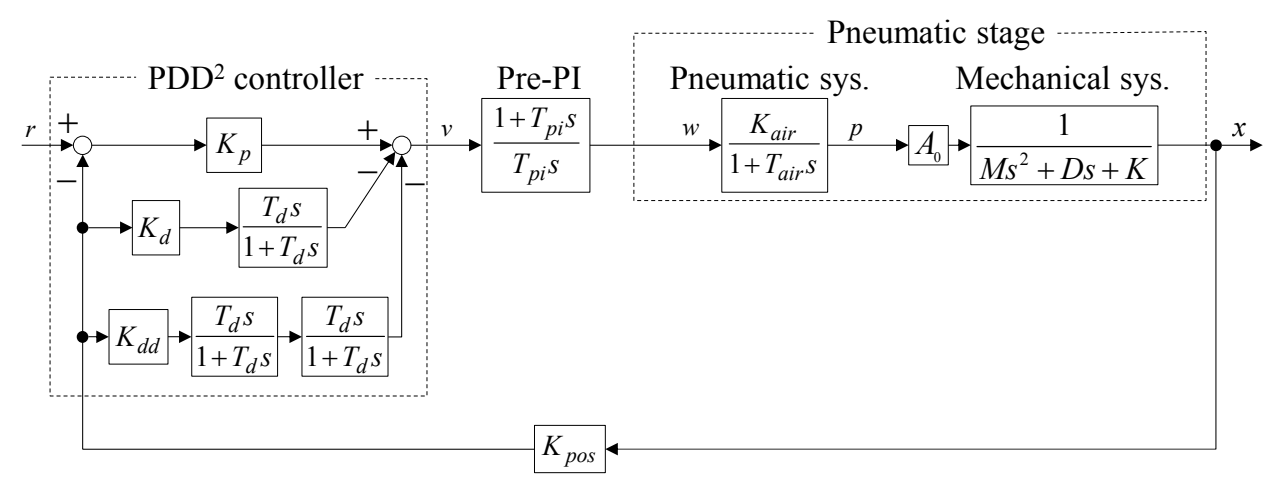

Fig.3 Control system of the pneumatic stage.

Table 1 Parameters of Fig.3.

\begin{tabular}{|c|c|c|c|c|c|}
\hline Symbol & Description & Unit & Symbol & Description & Unit \\
\hline$r$ & Reference & $\mathrm{V}$ & $T_{p i}$ & Time constant of Pre-PI compensator & $\mathrm{s}$ \\
\hline$v$ & Output of $\mathrm{PDD}^{2}$ compensator & $\mathrm{V}$ & $K_{\text {air }}$ & Gain of pneumatic system & $\mathrm{Pa} / \mathrm{V}$ \\
\hline$w$ & Input voltage to servo valves & $\mathrm{V}$ & $T_{\text {air }}$ & Time constant of pneumatic system & $\mathrm{s}$ \\
\hline$p$ & Differential pressure in pneumatic cylinder & $\mathrm{Pa}$ & $A_{0}$ & Piston area & $\mathrm{m}^{2}$ \\
\hline$x$ & Position of pneumatic stage & $\mathrm{m}$ & $M$ & Stage mass & $\mathrm{kg}$ \\
\hline$K_{p}$ & Proportional gain of $\mathrm{PDD}^{2}$ compensator & $\mathrm{V} / \mathrm{V}$ & $D$ & Viscous damping coefficient of stage & $\mathrm{N} \cdot \mathrm{s} / \mathrm{m}$ \\
\hline$K_{d}$ & Stiffness gain of $\mathrm{PDD}^{2}$ compensator & $\mathrm{V} / \mathrm{V}$ & $K$ & Spring constant of stage & $\mathrm{N} / \mathrm{m}$ \\
\hline$K_{d d}$ & Damping gain of $\mathrm{PDD}^{2}$ compensator & $\mathrm{V} / \mathrm{V}$ & $K_{p o s}$ & Detection sensitivity of LVDT & $\mathrm{V} / \mathrm{m}$ \\
\hline$T_{d}$ & Time constant of pseudo differentiator & $\mathrm{s}$ & & & \\
\hline
\end{tabular}

器を用いる（藤田他，2006）。同補償器を用いて，ステージ位置をPID 制御する。ただし，1 次遅れでモデル化 される空圧系を積分系へ周波数整形するために, 時定数について $T_{p}=T_{a i r}$ を満たすPI 補償器の前置が必須である. このとき, 目標值 $r$ から LVDT 出力 $K_{p o s} x$ までの伝達関数は

$$
\frac{K_{p o s} x}{r}=\frac{K_{p} K_{\text {air }} A_{0} K_{\text {pos }}}{T_{p i} s\left\{M s^{2}+(D+\Delta D) s+(K+\Delta K)\right\}+K_{p} K_{\text {air }} A_{0} K_{p o s}}
$$

であり，

$$
\begin{gathered}
\Delta D=\frac{K_{d d} K_{a i r} A_{0} K_{p o s} T_{d}^{2}}{T_{p i}} \\
\Delta K=\frac{K_{d} K_{a i r} A_{0} K_{p o s} T_{d}}{T_{p i}}
\end{gathered}
$$

となる. なお, 式(1)の伝達関数の導出においては, $\mathrm{PDD}^{2}$ 補償器中の擬似微分器を完全微分器に簡略化している. 式(1) (3)より，粘性項に含まれる $\mathrm{D}^{2}$ 制御のゲイン $K_{d d}$ にる粘性付与，剛性項に含まれる D制御のゲイン $K_{d}$ による剛性付与が可能である。位置決め応答において，前者はオーバシュートの抑制，後者は応答周期の短縮 をもたらす。

\section{$2 \cdot 3$ 位置決め}

空圧ステージを電子ビーム露光装置内に応用するためには，オーバシュートのない高速・高精度な駆動が要 求される. 同ステージの高速駆動を実現する制御手法として，1 章で SJFB や PresFB を挙げた. 前者ではジャー ク信号を, 後者では差圧信号を用いたフィードバックループを付加し, $\mathrm{PDD}^{2}$ 補償器と合わせてバルブ操作量が 決定される。しかし，両者ともに，左右のサーボバルブで給排気される空気の流量や，流量に呼応した圧力変 
化を評価していない，空気圧駆動が本質的に圧力制御系であるという観点からすれば，流量や圧力の制御性能 を向上させることでさらなる位置決め性能の向上を見込める.

そこで，まずは空圧ステージ駆動時の流量と圧力を測定する. 図 3 の制御系を用いて 2 秒後にプッシュ・プ ル駆動させた際の左側チャンバでの流量と圧力の応答を図 4 に示寸．なお，プッシュ動作は図 2 においてステ ージのストローク中央位置を原点 $(0 \mathrm{~mm})$ として右へ $12 \mathrm{~mm}$, プル動作はプッシュ動作後のステージを左へ駆動 し，原点復帰させる動作を意味する．また，流量が正のときに空気はバルブからチャンバ，負のときにチャン バからバルブの向きに流れる．図 4 右上より，プル動作のために左側バルブが排気動作を行うときの流量は, 同図左上に示される給気時のそれと比較して極めて小さく, 流量応答は非対称的である. また, 同図左下より, プッシュ動作のために同バルブが給気動作を行って左側チャンバの内圧が上昇するだけでなく，同図右下のよ うに，プル動作のために排気動作を行うときもチャンバ圧は上昇する. このとき, 位置決め時のチャンバ内圧 が両側ともに上昇するため, チャンバ間に生じる圧力差は小さくなる，その結果，ステージの応答は緩慢にな る.ゆえに，ステージの高速な駆動を阻害する排気側のチャンバ圧上昇を避けねばならない.

ここで, 排気側のチャンバ圧上昇の原因について検討する. 位置決め時の圧力応答を決定する要素として, 各バルブによる空気の給排気に伴う圧力変化と，ピストンの運動によるチャンバ体積変動に伴う圧力変化が挙 げられる．前者が後者に対して支配的ならば，給気側では圧力が上昇し，排気側では低下寸る．しかし，図 4 右上より，排気側における空気の流量は極端に少ない，そのため，実際の応答では，ピストンの運動によるチ ヤンバ体積减少がもたらす圧力上昇が支配的となり, 排気側のチャンバ圧力が上昇する. 他方で, 排気時の流 量を給気時と同等に増加すれば，圧力を低下させることができる.

\section{3. バルブ開度の非線形制御と圧力応答の改善}

\section{$3 \cdot 1$ 排気側のバルブに対する開度操作}

$2 \cdot 3$ 節で既述のように, バルブの排気動作時の流量が少なく, チャンバ内圧が上昇するため, ステージの応 答は緩慢となる，そのため，バルブの非線形な入出力特性を補償する制御ではなく，排気側の流量を増やし， 圧力を低下させる制御系の設計が必要となる. 文献（宮田，花房，1990）では，圧力応答に対するピストンの 運動の影響をフィードフォワード補償により打ち消し，排気側の圧力が低下寸るようになった。ささらに文献（宮 田他，1990）では，位置決め時の左右のチャンバ体積の違いを可変ゲイン圧力制御系で補償し，全ストローク にわたって左右のチャンバの圧力応答を均一, かつ同一にした. しかし, 両文献ともにピストン運動やチャン バ体積が圧力応答に与える影響の補償に重きを置いているため, 制御系が複雑となり調整コストが大きくなる. そこで，簡単に圧力応答を整形できる制御系を提案する.

バルブ操作量 $w$ から左右のバルブ操作量 $w_{\text {left }}, w_{\text {right }}$ を出力する制御系を図 5 に示す. 同図中の記号について, $w_{\text {left }}$ : 左側バルブの操作量[V], $w_{\text {right }}$ : 右側バルブの操作量[V], $K_{\text {left, }}, K_{r i g h t}$ : バルブ操作量の排気側ゲイン[V/V], $K_{\text {valve }}$ : バルブ操作量のゲイン $[\mathrm{V} / \mathrm{V}]$, Bias1, Bias2 : 予圧[V], とする. 同図(a)は従来の制御系であり, (b)が提案

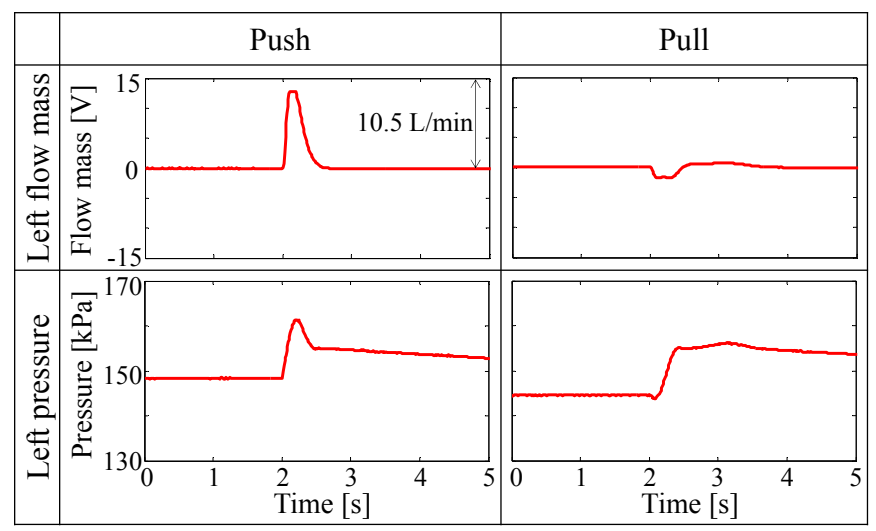

Fig.4 Flow mass and pressure responses. During push operation, air flows into the left chamber from the valve, and the pressure rises. During pull operation, air flows out from the chamber to the valve, but the pressure rises rather. 


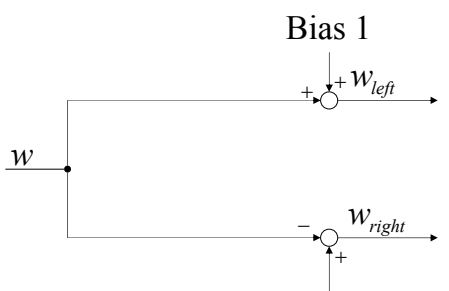

Bias 2

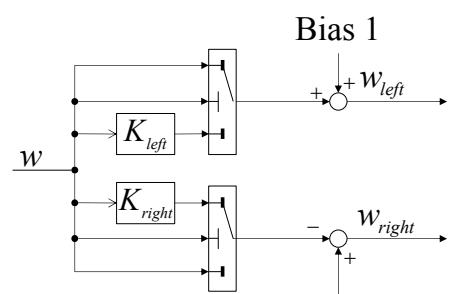

Bias 2

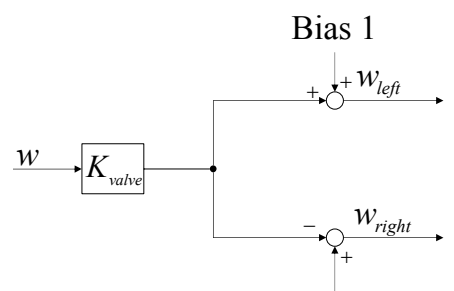

Bias 2

(a) Conventional

(c) Hypothetical

Fig. 5 Control system of the valve input.

のものである. (c)については 3 ・2 節で後述する. (a)では，各バルブに極性を反転させた大きさの等しい $w_{\text {left }}$, $w_{\text {right }}$ が出力される，一方，(b)では， $w$ を切替信号とするスイッチにより，wに乗算するゲインをスイッチング させる. ただし，スイッチの閾值は 0 に設定する.このとき， $w$ の極性からステージの駆動方向を判別し，排気 動作側のバルブ操作量にのみ排気側ゲイン $K_{\text {left }}, K_{\text {right }}$ が乗算される. そのため, 排気動作側のバルブ操作量のみ に $K_{\text {left }}$ または $K_{\text {right }}$ を乗算した $w_{\text {leftr }}, w_{\text {right }}$ が出力される.つまり，排気動作側のバルブ開度のみを制御し，流量を 増や寸ことが可能である.これにより，排気側に関しても給気側と同様に，ピストンの運動に伴う圧力変化に 対して各バルブの給排気に伴う圧力変化が支配的になるとき，チャンバ圧力は適切に低下する.

そこで, 排気側ゲイン $K_{\text {left }}, K_{\text {right }}$ を $1.0,1.5,2.0$ と変化させ, バルブ開度を非対称としたときの流量と圧力を 確認する. 図 5(b)を用いて 2 秒後にプッシュ・プル駆動させた際の流量と圧力の応答を図 6 に示す. 同図右上よ り，ゲイン増加に伴って排気時の流量は増加する．そのため，同図右下のように，排気側のチャンバ圧力が意 図したとおり低下寸る. 寸なわち, ピストンの運動に伴う圧力変化よりも各バルブの排気に伴う圧力変化が支 配的となる.ささらに, 図 6 下段の左右を比較して, $K_{\text {left }}, K_{r i g h t}=2.0$ では給気時と排気時の圧力応答がほぼ対称とな る.また，両チャンバともに圧力の収束が速くなる．以上より，バルブ開度を非対称とし排気をスムーズにす ることで，両チャンバ内の圧力特性を改善できた．ただし，流量計の出カレンジの制約から同図左上の流量の 測定結果に飽和を生じた．以降の実験結果においても，プッシュ動作時の流量は飽和する．なお， $K_{\text {left }}, K_{r i g h}=1.0$ のときの制御系は，同図中の(a) と等価となる.

さらに, $K_{\text {left }}, K_{\text {right }}$ の最適值を 2.0 として, $\mathrm{PDD}^{2}$ 補償器を構成する剛性ゲイン $K_{d}$ と粘性ゲイン $K_{d d}$ を調整して オーバシュートを抑制し，再度位置決めを行った結果を図 7 に示寸. 同図より, バルブ開度の非対称化は排気 側のチャンバ内圧を低下させる（同図(b)の $K_{\text {left }}, K_{r i g h t}=2.0$, w/o adjust)。これにより，応答が高速化する（同図(a) の $K_{\text {left, }} K_{\text {right }}=2.0$, w/o adjust). しかし, 立ち上がりの高速化に伴ってオーバシュートを生じる. そこで, $\mathrm{PDD}^{2}$ 補償器のゲイン調整によりオーバシュートを抑制する（同図(a)の w/ adjust)。このとき, 圧力応答が給気動作時 と排気動作時でほぼ対称となる（同図(b)のw/ adjust)。以上より，図 5(b)の手法では，文献（宮田他，1990）に

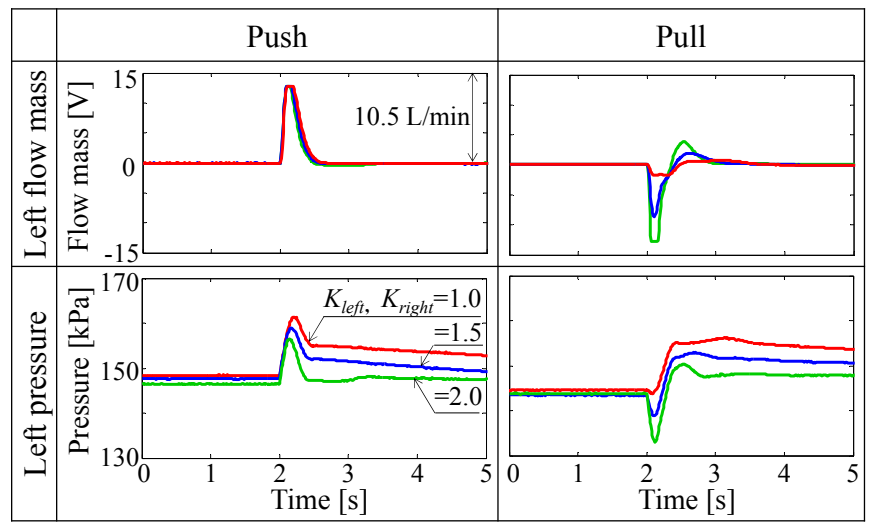

Fig. 6 Changing of flow mass and pressure responses due to $K_{\text {left }}$ and $K_{\text {right }}$. When $K_{\text {left }}$ and $K_{\text {right }}$ are increased, the flow mass of exhausted air increases and the pressure decreases. In case of $K_{\text {left }}, K_{\text {right }}=2.0$, the pressure response of the push and pull operation becomes almost symmetrical. 


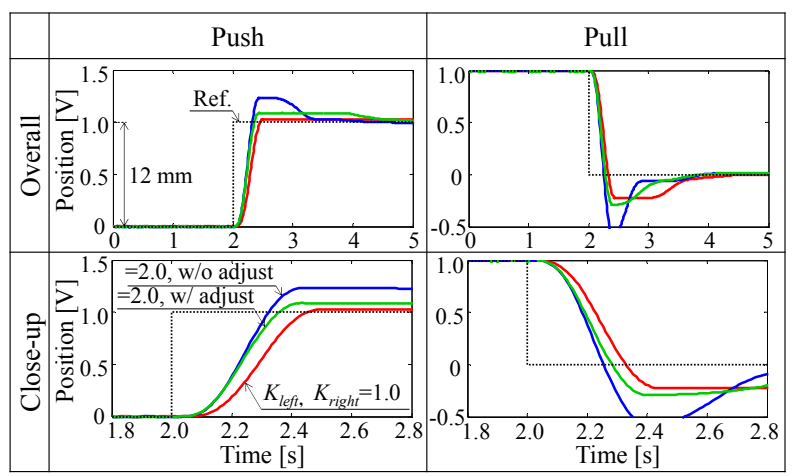

(a) Positioning responses

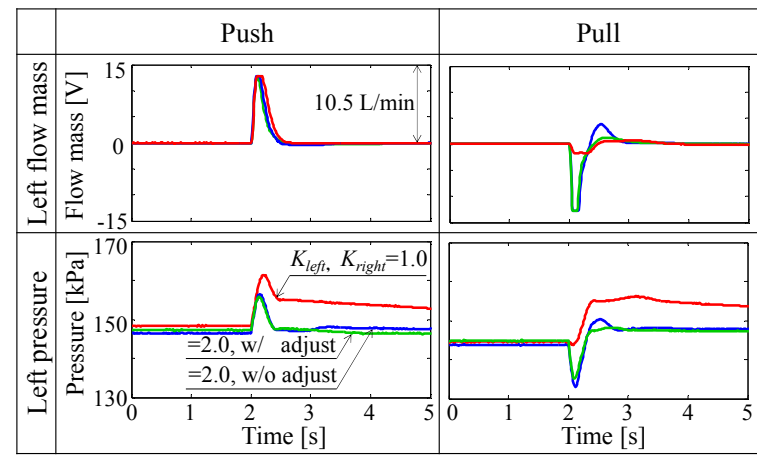

(b) Flow mass and pressure responses

Fig. 7 Results of positioning experiment. (a) shows that the positioning response speeds up by changing of $K_{\text {left }}$ and $K_{\text {right }}$. Furthermore, by adjusting the $\mathrm{PDD}^{2}$ compensator, the overshoot can be suppressed without deteriorating the rise time. In (b), it is presented that when $K_{\text {left }}, K_{\text {right }}=2.0, \mathrm{w} /$ adjust, which obtained the best positioning waveform, the pressure response of the push and pull operation are most symmetrical.

示される複雑な制御構成を用いずに左右の圧力応答を対称化し, 位置決め性能を向上できることが示された. また, $\mathrm{PDD}^{2}$ 補償器によるオーバシュートの抑制が圧力応答を変化させることから, 空圧ステージの位置制御が 本質的には圧力制御系であることを確認した。 なお，PDD補償器のゲイン調整は立ち上がりの高速化を劣化さ せることなくオーバシュートを抑圧できることを確認するために行った．したがって，定常偏差を最小限にす るような精緻なパラメータ調整を行ったわけではない. また, 同図(a)左側で確認できる定常偏差 (=2.0, w/ adjust) は，ステージの案内機構部の静止摩擦に起因寸る.

\section{$3 \cdot 2$ 両側のバルブに対する開度操作}

$3 \cdot 1$ 節では，排気側の圧力特性に着目し，バルブ操作量を非対称とすることで両チャンバの圧力応答を対称 化した，そのとき，位置決め応答は高速になる。しかし，実際に施す方策はゲインを増加させるという単純な ものである. そのため, 図 5(c)のように, スイッチを用いずに両側のバルブ操作量にゲインを乗算するだけで, 両チャンバ内圧の応答を改善するという方策も考えられる．本節では，この仮説が成立しないことを実験的に 示し，排気側の特性を考慮して非対称にバルブ開度を調整して圧力を対称化する方策の有効性を示す.

図 5(c)に示した制御系では，バルブ操作量のゲイン $K_{\text {valve }}$ を乗算し，各バルブには極性が反転した同一のバル ブ操作量 $w_{\text {left }}, w_{\text {right }}$ が入力される. なお， $K_{\text {valve }}=1.0$ のとき(a)と等価となる. (c)を用いて位置決め実験を行った ときの結果を図 8 に示す．同図(a)より， $K_{\text {valve }}$ を 1.0，1.2，1.4 と変化させると応答が高速化する．一方で，大幅 なオーバシュートを生じる．また(b)右上より，ゲインの増加は排気の流量をわずかに増やす．しかし，(b)右下 より, チャンバ圧力は十分に低下しない，そのため，圧力応答の整形という点では不十分であり，ピストンの

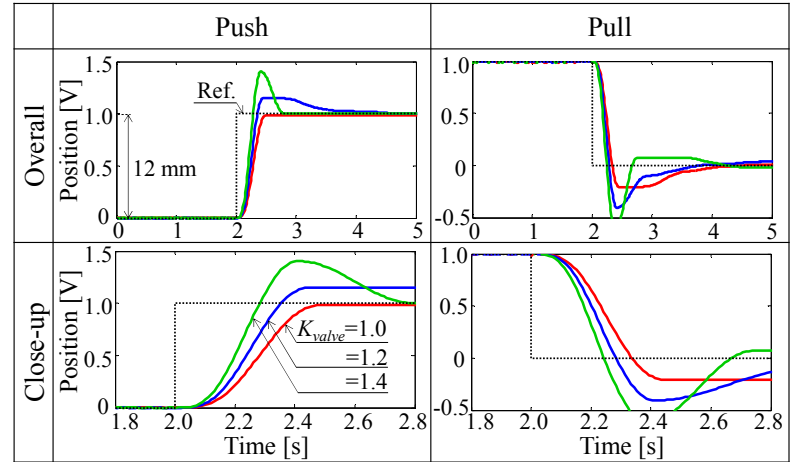

(a) Positioning responses

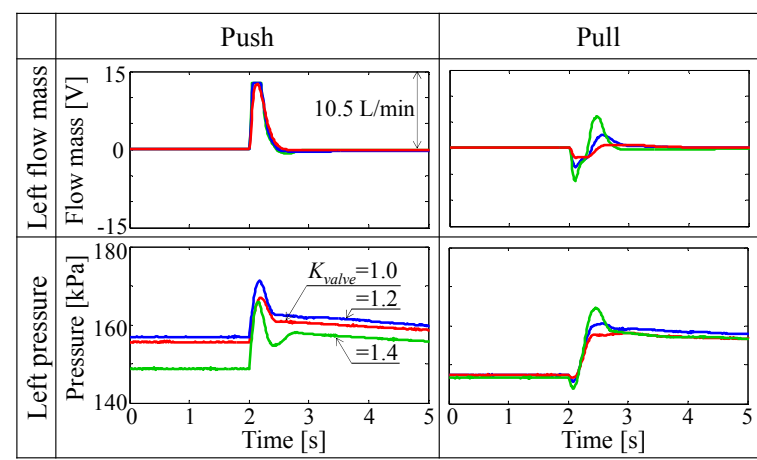

(b) Flow mass and pressure responses

Fig. 8 Results of positioning experiment for verification. (a) shows that the positioning response speeds up by increasing of $K_{\text {valve }}$, but the overshoot also increases. In (b), it is presented that the flow mass of exhausted air slightly increases, but it shows that the pressure hardly decreases as $K_{\text {valve }}$ increases. That is, it is insufficient to improve the pressure response. 
運動に伴う圧力変化が各バルブの給排気によるものよりも支配的な状態を解消できていない． $K_{\text {valve }}$ のさらなる 八イゲイン化による排気側のチャンバ圧力の低下を期待できるが，オーバシュートの増大によるステージ発振 の危険を伴うため現実的ではない. さらに, チャンバ圧力の収束の速さに関して目立った差異を認められない. つまり, 両チャンバの圧力特性を改善できていない，以上より，両側のバルブ操作量に対するゲインの乗算に よる両チャンバの圧力応答の整形は望めず，位置の定位性はオーバシュート増大により悪化するため，図 5(c) の制御系は図 5(b)と比較して劣っていることが示された．よって，3・1 節で示した非対称にバルブ開度を調整 する図 5(b)の方策の有効性が確認された.

\section{4. 制御系の併用}

\section{$4 \cdot 1$ 圧力制御系}

空気圧駆動が本質的に圧力制御系であるという点においては, 空圧ステージの緩慢な応答の改善に圧力信号 を用いた制御が有効である. 実際，チャンバ間の圧力差信号を用いた PresFB は同ステージの位置決め性能の向 上に寄与する（涌井，多田，2008）。また，3 章では，排気側のバルブに対する開度操作の適用による良好な圧 力応答が確認された．そのため，提案手法を他の制御系と併用するときにも，同様の効果を発揮することが期 待される. そこで，排気側のバルブに対する開度操作の空圧ステージへの一応用例として，PresFB との併用を 試みる。

図9にPresFB 適用時の空圧ステージの制御系を示寸. 図中で新たに用いた記号は, $w^{\prime}$ : Pre-PI 補償器の出力[V], $K_{p i}$ : Pres-PI 補償器のゲイン $[\mathrm{V} / \mathrm{V}], T_{p r e s}$ : Pres-PI 補償器の時定数[s], $K_{\text {pres }}$ : 圧力センサ感度[V/Pa], $K_{p f b}:$ PresFB

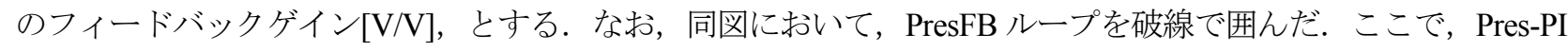
補償器の時定数 $T_{\text {pres }}$ を空圧系のそれと一致させる. この条件下で $K_{p i}$ を増加させることで, 1 次遅れの空圧系の 折点周波数を高周波へシフトできる．これにより，ステージを高速駆動できる．ただし，PresFB では左右の圧 カセンサ出力の差分をとって圧力差情報を得る. そのため, 右側のチャンバ圧を測定する圧力センサの出力信 号を DSP に入力信号に加え, 差圧信号を右側チャンバの圧力信号から左側の信号を DSP 内で減算して取得でき るように実験構成を変更した.

\section{$4 \cdot 2$ PresFB の適用}

4 ・1 節で詳述した図 9 の PresFB を適用した制御系を用いて, 位置決めを 3 回ずつ行ったときの結果を図 10 に示す，同図中に示した従来手法では図 5(a)の，提案手法では(b)の制御系を用いている．また，Pres-PI 補償器 のゲイン $K_{p i}$ を前者では 1.1 に，後者では 1.0 に調整した，そのため，八イゲインに設定した従来手法は立ち上 がりの速さという点では提案手法よりも優れているはずである.しかし，図 10(a) の位置決め波形より，提案手 法の方が高速な応答を得られる。これは，(b)の圧力波形において，従来手法では排気動作側の右圧力が位置決 め時に上昇するが，提案手法では十分に低下寸ることに起因する，つまり，PresFB を適用しても，空気の圧縮 性に起因した排気側の圧力上昇を生じる場合, 位置決め応答は緩慢になることを避けられない. また, 提案手

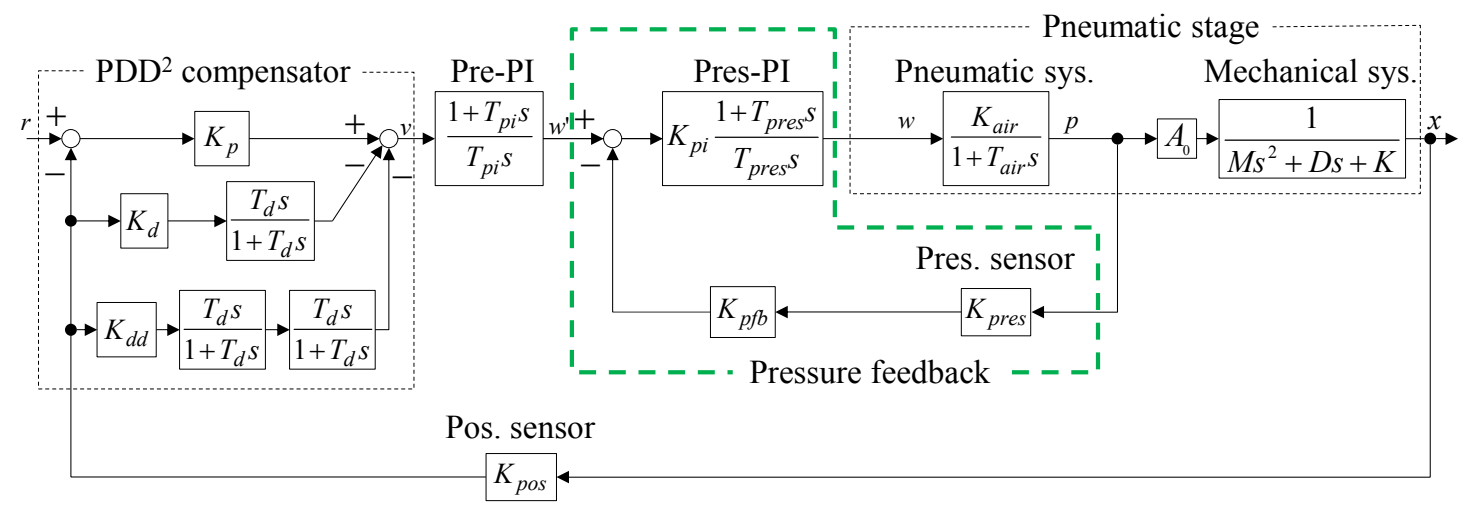

Fig. 9 Control system of the pneumatic stage with pressure feedback. 


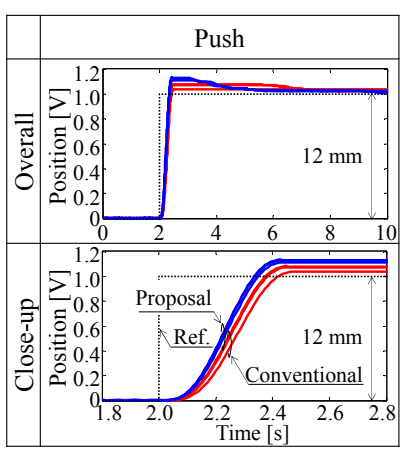

(a) Positioning responses

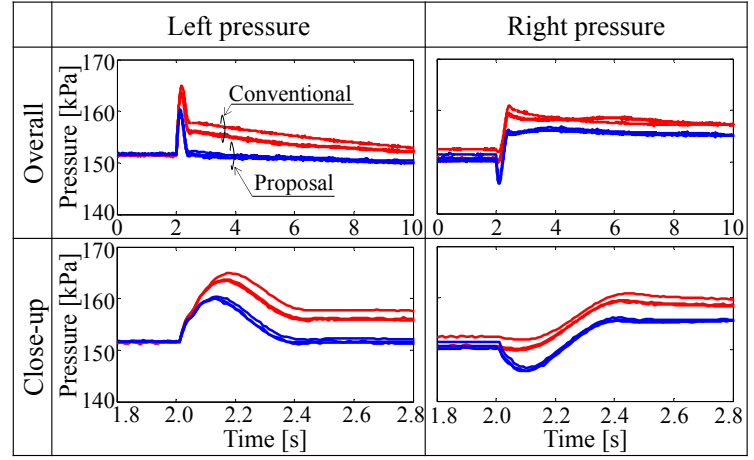

(b) Pressure responses

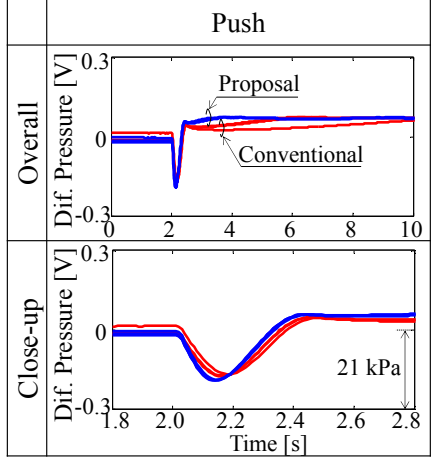

(c) Differential pressure responses

Fig. 10 Results of positioning experiment with pressure feedback. (a) shows that the proposed method is faster than the conventional method even if the difference of $K_{p i}$ is taken into consideration. In (b), it is presented that the left and right pressure response approaches symmetry when using the proposed method. In (c), it is shown that the differential pressure quickly converges by using proposal method.

法は圧力波形の収束という点でも従来手法より優れる.(c)の差圧波形においても, 提案手法は収束がわずかな がら速い。ここで, 左右のチャンバ圧力が収束せずに位置決めを開始すると, 差圧の初期值の差異により繰り 返し位置決めの精度が悪化する，そのため，同程度の位置決め時間を実現しても，内部状態の差圧がわずかで も速く収束する提案手法では繰り返し位置決めの精度向上を期待できる．以上より，提案手法による位置およ び圧力の応答の改善が確認され，PresFB 制御系の適用時における排気側のバルブに対する開度操作の有効性が 示された.

\section{5. 結言}

結論は以下のとおりである.

(1) 空圧ステージの駆動時に, 両側のシリンダ内のチャンバ内圧が上昇した. 給気側の圧力を上昇させ, 排気 側を低下させる圧力応答の対称化を実現することにより，位置決め応答は高速化する.

(2) 圧力応答を改善する一手法として, 排気側のバルブ開度操作を行った．排気側のバルブ開度のみを大きく し, 給気側と排気側のバルブ開度を非対称にすることで, 圧力応答を改善できることを実験的に確認した. さらに，位置決め応答の良化も確認した。

(3) PresFB を用いた制御系に対して排気側のバルブ開度操作を行ったときも，圧力応答および位置決め応答が 改善する．以上より，他の制御系との併用時においても排気側のバルブ開度操作の有効性が示された.

\section{文献}

藤田壽憲, 小島英介, 田島正之, 宮島隆至, 榊和敏, 川嶋健嗣, 香川利春, サーボ弁の動特性を考慮した空気圧サ ーボシステムの制御系設計, 日本機械学会年次大会講演論文集, Vol.2, No.2 (2006), pp.309-310.

Ito, N., Wakui, S. and Nakamura, Y., Pneumatic stage positioning with model following control and PDD $^{2}$ control, International Journal of Advanced Mechatronic Systems, Vol.6, No.6 (2016), pp.247-257.

加藤友規, 品川大輔, 只野耕太郎, 川嶋健嗣, 香川利春, 加速度・速度・流量フィードバックによる鉄道台車の鉛 直空気ばねの制御,「運動と振動の制御」シンポジウム講演論文集, Vol.11 (2009), DOI: 10.1299/jsmemovic.2009.11.470.

Kawashima, K., Arai, T., Tadano, K., Fujita, T. and Kagawa, T., Development of coarse/fine dual stage using pneumatically driven bellows actuator and cylinder with air bearings, Precision Engineering, Vol.34, No.3 (2010), pp.526-533.

京和泉宏三, 藤田行茂, 岩井善太, 水本郁朗, 一般産業用空圧シリンダの位置決め制御, 日本フルードパワーシス テム学会論文集, Vol.35, No.6 (2004), pp.97-102.

宮田慶一郎, 花房秀郎, 圧力制御を主体とした空気圧シリンダの速度制御, 計測自動制御学会論文集, Vol.26, No.7 (1990), pp.773-779.

宮田慶一郎, 石田公成, 花房秀郎, 可変ゲイン圧力制御系を含む二重構造フィードバック制御による空気圧シリ 
ンダの位置決め, 計測自動制御学会論文集, Vol.26, No.7 (1990), pp.787-794.

白石貴行, 涌井伸二, 高橋正人, 空圧式除振装置の配管共振抑制法, 精密工学会誌, Vol.73, No.2 (2007), pp.259-264.

涌井伸二, 多田遼太郎, 圧力フィードバックと直列補償を備えた空圧系の位置決め制御, 精密工学会誌, Vol.74, No.7 (2008), pp.769-774.

Wali, M. and Wakui, S., Positive stage jerk feedback combined with positive base plate jerk feedback to improve the positioning speed of a pneumatic stage, Journal of Advanced Mechanical Design, Systems, and Manufacturing, Vol. 7, No. 2 (2013), pp. 219-232.

柳川敦志, 涌井伸二, 空圧ステージへの流量外乱オブザーバ付き完全 2 自由度 $\mathrm{PDD}^{2}$ 制御の適用, 日本機械学会論 文集 C 編, Vol.76, No.766 (2010), pp.1496-1502.

\section{References}

Fujita, T., Kojima, E., Tajima, M., Miyajima, T., Sakaki, K., Kawashima, K. and Kagawa, T., Control system design of pneumatic servo system considering dynamic characteristics of servo valve, JSME annual meeting, Vol.2, No.2 (2006), pp.309-310 (in Japanese).

Ito, N., Wakui, S. and Nakamura, Y., Pneumatic stage positioning with model following control and PDD $^{2}$ control, International Journal of Advanced Mechatronic Systems, Vol.6, No.6 (2016), pp.247-257.

Kato, T., Shinagawa, D., Tadano, K., Kawashima, K. and Kagawa, T., Active control of vertical vibration of pneumatic air spring for rail train using acceleration, velocity and flow rate feedbacks, The Proceedings of the Symposium on the Motion and Vibration Control, Vol.11(2009), DOI: 10.1299/jsmemovic.2009.11.470 (in Japanese).

Kawashima, K., Arai, T., Tadano, K., Fujita, T. and Kagawa, T., Development of coarse/fine dual stage using pneumatically driven bellows actuator and cylinder with air bearings, Precision Engineering, Vol.34, No.3 (2010), pp.526-533.

Kyoizumi, K., Fujitta, Y., Iwai, Z. and Mizumoto, I., Positioning control of pneumatic cylinder used in general industries, Transactions of the Japan Fluid Power System Society, Vol.35, No.6 (2004), pp.97-102 (in Japanese).

Miyata, K. and Hanafusa, H., Velocity control of pneumatic cylinders by using pressure control, Transactions of the Society of Instrument and Control Engineers, Vol.26, No.7 (1990), pp.773-779 (in Japanese).

Miyata, K., Ishida, K. and Hanafusa, H., Double structured feedback control with variable gain pressure control system for positioning of pneumatic cylinders, Transactions of the Society of Instrument and Control Engineers, Vol.26, No.7 (1990), pp.787-794 (in Japanese).

Shiraishi, T., Wakui, S. and Takahashi, M., Method of pipe resonance suppression for an air type anti-vibration apparatus, Journal of the Japan Society for Precision Engineering, Vol.73, No.2 (2007), pp.259-264 (in Japanese).

Wakui, S. and Tada, R., Positioning control using pressure feedback and series compensator for pneumatic system, Journal of the Japan Society for Precision Engineering, Vol.74, No.7 (2008), pp.769-774 (in Japanese).

Wali, M. and Wakui, S., Positive stage jerk feedback combined with positive base plate jerk feedback to improve the positioning speed of a pneumatic stage, Journal of Advanced Mechanical Design, Systems, and Manufacturing, Vol. 7, No. 2 (2013), pp. 219-232.

Yanagawa, A. and Wakui, S., Application of perfect 2 DOF PDD $^{2}$ control with flow disturbance observer for a pneumatic stage, Transactions of the Japan Society of Mechanical Engineers, Series C, Vol.76, No.766 (2010), pp.1496-1502 (in Japanese). 